\title{
MECANISMOS DE PRODUÇÃO DE HUMOR NOS EPIGRAMAS DE MARCIAL
}

\author{
ROBSON TADEU CESILA* \\ Instituto de Estudos da Linguagem \\ Universidade de Campinas
}

\begin{abstract}
RESUMO: O objetivo deste artigo é descrever e comentar alguns mecanismos - lexicais, sintáticos, morfológicos, semânticos, intertextuais - utilizados pelo poeta marcial para produzir humor em seus epigramas.
\end{abstract}

PALAVRAS-CHAVE: epigrama; Marcial, humor, riso.

O objetivo deste estudo é descrever alguns mecanismos que atuam na produção do humor nos poemas do epigramatista latino Marco Valério Marcial, que viveu e produziu nos séculos I e II de nossa era. Inicialmente, por razões didáticas, tentarei tratar dos mecanismos separadamente, mas é óbvio que mais de um mecanismo pode estar envolvido (e geralmente está) na produção do humor, fato a que já chamara a atenção Possenti (1998: 27) ao analisar os textos das modernas piadas. Assim, vários mecanismos acabarão sendo tratados ao mesmo tempo, embora eles devam esperar o tópico apropriado para serem os protagonistas da análise.

\section{O fecho cômico-espirituoso}

A técnica de deixar para o final do epigrama os elementos responsáveis pelo humor nele presente foi descrita por diversos estudiosos atuais (Conte, 1994: 508; Gentili, 1987: 437-438; Citroni et al., 1991: 187; Martin \& Gaillard: 1981: 409), mas já Gotthold Ephraim Lessing, no século XVIII, resumia a teoria da es-

\footnotetext{
* Doutorando em Lingüística/Letras Clássicas no Insituto de Estudos da Linguagem da Universidade de Campinas.
} 
trutura bipartida do epigrama, que seria composto de uma primeira parte mais extensa, que expõe, explica, desenvolve o tema do poema, criando uma tensão e uma expectativa no leitor, e uma segunda parte, em geral correspondente ao último verso ou às últimas palavras do poema, que contém a frase picante, o dito mordaz, o comentário inteligente e espirituoso, os elementos, enfim, responsáveis pelo humor e pela graça do epigrama (apud Swann, 1994: 150).

Vejamos o epigrama 26 do livro III:

Praedia solus habes et solus, Candide, nummos, aurea solus habes, murrina solus habes,

Massica solus habes et Opimi Caecuba solus, et cor solus habes, solus et ingenium.

Omnia solus habes - nec me puta uelle negare uxorem sed habes, Candide, cum populo.

Só pra ti tens imóveis, Cândido, e dinheiro, só pra ti tens taças de mirra e de ouro, só pra ti Mássicos e Cécubos opímios, e um gênio e um talento tens só pra ti.

Tudo tens só pra ti - isso eu não vou negar -, mas tens uma esposa em comum com o povo.

Marcial se dirige a um certo indivíduo chamado Cândido e, através de um procedimento que alia repetição e amplificação, nos apresenta qual é o traço (para o poeta, um defeito moral) que o caracteriza: Cândido é um rico avarento, mesquinho, que guarda para si todos os seus bens (v. 1), seu rico aparato de mesa (v. 2), seus vinhos de excelente qualidade (v. 3) e até mesmo certos dons não materiais que se costuma "dar", "partilhar" com os outros, como a inteligência e o talento (pode-se ver, nesses dois últimos casos, um exemplo de procedimento hiperbólico, de exageração por parte do poeta, já que dificilmente alguém se recusaria a "partilhar", divulgar seu talento ou inteligência). Note-se como o "defeito" de Cândido é descrito, construído e amplificado aos poucos, através de constantes repetições, que, em razão da métrica que adotei (versos dodecassílabos para os hexâmetros latinos e decassílabos para os pentâmetros), não pude reproduzir totalmente em minha tradução: a expressão solus habes (“tens sozinho", isto é, "tens só para ti”) é empregada em todos os cinco versos iniciais, culminando no v. 6, em que se opõe 
a habes cum populo ("tens com o povo", isto é, "tens como todo mundo", "partilhas com todo mundo"). O humor, como se vê, fica para o verso final (mais precisamente, para as duas palavras finais do poema, que constituem o "gatilho" do humor, cf. Possenti, 1998: 23), e a intensidade do efeito humorístico está relacionada, sem dúvida, ao processo de amplificação gradativa presente nos cinco versos anteriores. O humor final se deve à contraposição entre o constantemente repetido solus habes e o habes cum populo do último verso, em que há, portanto, uma quebra, uma mudança repentina.

Duas interpretações seriam possíveis para o humor final do poema. A primeira, menos preferível, é de que Cândido seria um marido traído condescendente: ele sabe que sua esposa o trai (sabe que partilha sua esposa com todo mundo), mas considera mais importante guardar só para si seus bens materiais, não se importando em "dividir" a esposa. Assim, sua postura é, na visão do poema, condenável, pois permite partilhar justamente aquilo que qualquer marido faria questão de guardar só para si (é bom lembrar que a sociedade romana antiga, ao contrário do que o cinema nos quer fazer acreditar, era extremamente conservadora em muitos de seus aspectos, inclusive em relação à sexualidade; assim como hoje, as mulheres eram em geral privadas de liberdades a que os homens se permitiam).

A outra interpretação é a de que Cândido não sabe que é traído pela mulher, o que aumenta o efeito humorístico presente no último verso e construído nos cinco versos precedentes. Marcial diz algo como: "olha, Cândido, enquanto tu te preocupas em não partilhar com os outros teus imóveis, teu dinheiro, tuas taças, teu vinho e teu talento, tu estás, sem o saber, partilhando a esposa com todos, pois ela está te traindo". Resta dizer por que considero preferível essa segunda interpretação e, para isso, evoco outro procedimento de produção de humor comum nos epigramas de Marcial.

\section{O humor dos nomes próprios}

O adjetivo latino candidus, a exemplo da palavra portuguesa dele derivada, significa "branco", "alvo", mas também, por extensão de sentido, "puro", "inocente”, "ingênuo". Assim, ao chamar Candidus ao indivíduo a quem se dirige, Marcial alude a uma possível ignorância ou desconhecimento, por parte daquele, da traição da esposa. Isso sem dúvida aumenta o efeito humorístico do fecho cômico e torna essa segunda interpretação mais interessante que a primeira. 
Vê-se, assim, que um nome próprio contribui na produção do humor. No caso de Candidus, o humor se baseia no fenômeno da ambigüidade lexical ou polissemia, de que pretendo tratar mais adiante.

Os nomes próprios como elementos produtores de humor são abundantes na poesia de Marcial, como, aliás, na obra de muitos escritores (Cf. Propp, 1992: 204-206, que fornece exemplos em escritores russos). Fidentinus (Fidentino) é geralmente o nome dos plagiários que Marcial ataca ${ }^{1}$ (o termo contém a raiz de fides, "fé", "lealdade", "retidão", "honestidade", numa intenção claramente irônica, com quebra de expectativas); Sabellus (Sabelo) ocorre em XII.39 como o nome de um "arrumadinho" efeminado (o adjetivo bellus, aplicado a um homem, designava o indivíduo que se arrumava em excesso, chegando a ser, por isso, efeminado); Apicius (Apício) é o nome dado aos glutões (houve um famoso e glutão cozinheiro romano de nome Apício, que viveu na primeira metade do século I d.C.); etc. ${ }^{2}$

Veja-se este outro epigrama (VII.83):

\title{
Eutrapelus tonsor dum circuit ora Luperci
} expingitque genas, altera barba subit.

\author{
Quando Eutrápelo a barba perfaz de Luperco, \\ no outro lado outra barba já cresceu.
}

1 Cf. os epigramas I.38, I.53 e I.72. Ver também Cesila, R. T. "Marcial e as origens do termo plágio". In: Cesila, R. T. Metapoesia nos epigramas de Marcial: tradução e análise. Dissertação de Mestrado em Lingüística/Letras Clássicas. Campinas: Instituto de Estudos da Linguagem, 2004, p. 371-389.

2 Devo aqui fazer uma observação indispensável sobre os nomes próprios na poesia de Marcial. Todos os nomes próprios utilizados por ele para nomear indivíduos satirizados, estejam esses nomes sendo ou não usados para produzir humor, devem ser encarados como falsos nomes, pseudônimos, pois o próprio escritor afirma, no prefácio a seu primeiro livro, que não ataca ninguém por seu nome verdadeiro. Os nomes próprios, nesses casos, ou designam um indivíduo específico cuja identidade o poeta não quer revelar, ou, de maneira genérica, um tipo social que é alvo das farpas do epigramatista. "Fidentino", por exemplo, pode ser 1) um único plagiário criticado pelo poeta nos três epigramas mencionados na nota $1 ; 2)$ o tipo social "plagiário", que era comum, ao que parece, na sociedade romana dos primeiros séculos do Império. O que seria improvável é que Fidentino fosse um plagiário que tivesse, na vida real, esse nome.

Nos epigramas em que os indivíduos mencionados recebem homenagens e elogios, os nomes devem, obviamente, ser encarados como verdadeiros, como ocorre nos epigramas fúnebres e nos encomiásticos, muitos deles dirigidos aos imperadores e a patronos e amigos de Marcial. 
Creio que não há problema em apreender aqui o humor do epigrama, acionado pela seqüência situada depois da cesura do pentâmetro, isto é, por altera barba subit ("outra barba cresce"). A intenção é, evidentemente, criticar a lentidão desse barbeiro, que, enquanto termina a volta ao rosto de seu cliente Luperco, outra barba já cresceu nas partes já barbeadas. Eutrápelo é tão lento que, antes mesmo de terminar de fazer a barba, esta já cresceu de novo.

Esse dístico de Marcial exemplifica também a técnica do "fecho cômico", já que o humor se situa essencialmente nas últimas palavras do poema, "outra barba cresce" (embora a conjunção temporal dum, "enquanto", que é crucial na produção do humor nesse caso, esteja no primeiro verso). Mas o que quero de fato exemplificar com esse epigrama é o humor dos nomes próprios Eutrapelus e Lupercus. O primeiro vem do adjetivo grego ejutravpelo" (eutrápelos), que significa "ágil", "ligeiro", o que contrasta - e mais do que isso, se opõe - à característica que tem de fato o indivíduo satirizado: a lentidão. $\mathrm{O}$ procedimento envolve, portanto, a ironia, uma vez que se diz, com Eutrapelus, algo diferente daquilo que se quer dar a entender. Quanto a Lupercus, é fácil perceber que se tem aí a raiz do substantivo lupus ("lobo"), um animal que tem muitos pêlos. Assim, o poeta satiriza ao mesmo tempo o barbeiro, nomeando-o ironicamente (Eutrapelus), e satiriza o cliente, sugerindo que sua barba cresce rápido demais, que ele é peludo como um lobo (Lupercus). Os dois nomes próprios são sugestivos, expressivos, e contribuem na produção do humor do epigrama.

\section{O papel do leitor}

Mas será que os significados desses dois nomes próprios são essenciais para que haja humor no poema em questão? Parece que não. Basta ao leitor entender que o barbeiro de que se trata é tão lento que, ao terminar de barbear seu cliente, a barba deste já cresceu novamente. Os significados expressivos dos nomes próprios Eutrapelus e Lupercus contribuem, vêm somar, para a produção do humor; eles enfatizam, aumentam o humor, mas não são o principal mecanismo acionado para que se entenda a graça do epigrama. Mesmo que não se perceba a comicidade em potencial nesses nomes, pode-se rir da mensagem do poema. É por isso que nós, leitores do século XXI, podemos rir, achamos graça nesse epigrama. Mesmo não sendo nós os leitores (ou ouvintes) pressupostos pelo texto de Marcial, conseguimos captar o humor desses versos.

Para entender, além do humor essencial desse poema, o humor acessório presente nos dois nomes próprios, o destinatário deveria ter uma certa competên- 
cia lingüística e, em menor grau, um conhecimento de mundo. No caso de Lupercus, basta ao leitor analisar o termo e encontrar nele a raiz lup- de lupus, além de saber que o lobo é um animal peludo (conhecimento de mundo). Quanto a Eutrapelus, é necessário um conhecimento da língua grega, o que, numa sociedade em que muitos eram bilíngües (grego e latim) como a romana, não era exigência demasiada. Isso não deixava, por outro lado, de vedar a muitos outros, que não sabiam grego, a apreensão do humor desse nome próprio. Essa é a situação também do leitor de Marcial hoje: excetuando-se um pequeno número de iniciados no grego, o humor do nome próprio Eutrapelus passaria despercebido e, talvez, do próprio termo Lupercus, cuja raiz lup- não é facilmente perceptível, a não iniciados, no substantivo "lobo".

Voltemos agora ao epigrama analisado anteriormente, sobre Cândido (III.26). Ele não oferece dificuldades na apreensão de seu humor, talvez porque o dado sócio-cultural envolvido em sua produção não tenha mudado nesses mil e novecentos anos que nos separam da época em que o poema foi produzido: o marido traído continua sendo motivo de troça e freqüenta assiduamente os textos humorísticos atuais. Mas há um dado, no terceiro verso do poema, que, apesar de não afetar a captação do humor do texto, é interessante para reforçar o que foi dito há pouco sobre o leitor no epigrama VII.83. Certamente o leitor de hoje não saberia, a não ser com a ajuda de notas explicativas, o que é um "Mássico" ou um "Cécubo" "opímios". Mas o leitor pressuposto/instituído pelo texto de Marcial certamente não teria problemas em saber que os substantivos neutros Massicum e Caecubum designavam dois dos mais famosos e apreciados vinhos da Antigüidade, produzidos nas regiões italianas da Campânia e do Lácio, respectivamente. ${ }^{3}$ Também sabiam que se poderia chamar de "Opímio" (Opimium) a qualquer vinho de excelente qualidade, e muitos até sabiam que Opímio (Opimius) fora um dos cônsules em 121 a.C., ano cuja safra produziu vinhos de excelente qualidade, e que o nome do cônsul passou a designar o vinho produzido naquele ano, e, depois, todo e qualquer vinho de boa qualidade. ${ }^{4}$ São informações a que nós, leitores de Marcial no século XXI, só temos acesso por meio de notas ou de obras especializadas.

3 Subentendia-se o substantivo neutro uinum ("vinho"): uinum Massicum, uinum Caecubum. Metonimicamente, os antigos se referiam aos vinhos simplesmente como "Mássico" e "Cécubo", da mesma forma que dizemos hoje "um borgonha" por "um vinho da Borgonha" e "uma garrafa de Porto" por "uma garrafa de vinho do Porto".

4 No poema de Marcial, tem-se o termo no genitivo: Massica et Opimi Caecuba ("vinhos Mássicos e Cécubos de Opímio", ou seja, "do tempo de Opímio”, “do consulado de Opímio"). 


\section{Intertextualidade ${ }^{5}$}

Nos dois epigramas até agora analisados, a intertextualidade não é um fator necessário nem acessório no efeito humorístico. É evidente que há algum intertexto em ambos, na medida em que nenhum discurso, seja ele qual for, se constrói ex nihilo (Maingueneau, 1996b: 27). Poder-se-ia pensar, por exemplo, no intertexto de cunho genérico presente em ambos, ou seja, nos elementos que unem esses dois poemas a um gênero, o epigrama. No plano do conteúdo, o marido traído e o barbeiro imperito são temas recorrentes da poesia epigramática (e isso não só na Antigüidade, como demonstra a obra de um Bocage, por exemplo). No plano formal, o humor, o fecho cômico, a brevidade, os esquemas métricos (o dístico elegíaco é o principal metro do gênero epigramático) e mesmo o vocabulário são elementos que demonstram a pertinência desses textos a toda uma tradição literária do epigrama, que se iniciou na Grécia arcaica.

Mas quero trazer aqui exemplos em que os procedimentos intertextuais contribuem mais diretamente, ou são mesmo os protagonistas, na produção do humor. O seguinte epigrama (X.67) exemplifica o primeiro caso:

Pyrrhae filia, Nestoris nouerca, quam uidit Niobe puella canam, Laertes auiam senex uocauit, nutricem Priamus, socrum Thyestes, iam cornicibus omnibus superstes, hoc tandem sita prurit in sepulchro caluo Plutia cum Melanthione.

Filha de Pirra, de Nestor madrasta, que idosa viu, ainda menina, Níobe; de avó Laertes a chamou, já velho, e de ama Príamo, e de sogra Tiestes; que às gralhas todas já sobreviveu;

5 Utilizo este termo de maneira bastante geral, designando qualquer relação que une um texto a outro(s). Aqui, então, "intertextualidade" equivale ao que Genette (1982: 7) chamou "transtextualidade". A classificação que esse estudioso faz dos tipos de transtextualidade, ainda que produtiva, não será aqui enfatizada, pois o que interessa é apenas mostrar quando e como os fenômenos intertextuais produzem humor. 
neste sepulcro, com Melântio, o calvo, posta enfim, Plútia de desejo ainda arde!

O humor essencial deste poema está no fato de que Plútia é uma mulher velha que, apesar da idade, ainda sente desejo sexual. Os idosos, na Roma Antiga, eram vistos como risíveis, a se acreditar nos epigramas de Marcial, se tinham comportamentos ou desejos de pessoas jovens, uma vez que fugiam ao paradigma de comportamento "esperado" para a sua idade.

Mas contribui para o humor final a imagem de senectude de Plútia que é construída no decorrer do poema (note-se que o nome da pessoa satirizada só aparece no último verso). É fácil perceber que o poeta utiliza o mesmo procedimento de enfatização gradativa usado no epigrama sobre Cândido: os cinco primeiros versos, por meio de várias hipérboles intertextuais, enfatizam a senectude de Plútia, criando uma tensão no leitor/ouvinte do poema. $\mathrm{O}$ auge do processo se encontra no penúltimo verso: mesmo depois de morta, enterrada junto de seu supõe-se - marido Melântio, Plútia ainda sente desejo sexual. O procedimento é, obviamente, baseado no exagero, na hipérbole (poderíamos imaginar, tomando de alguma liberdade em nossa interpretação, os apuros desse tal Melântio, que está enterrado per aeternitatem, no mesmo leito fúnebre, com essa velha insaciável). E ao menos seis desses elementos intensificadores se baseiam em processos intertextuais. O destinatário da mensagem tem de conhecer a mitologia grecolatina para captar o humor dessas hipérboles, e isso significa conhecer, de ter lido ou ouvido falar, outros textos, os quais trazem os personagens citados por Marcial. Teria de conhecer, no caso, sobretudo as epopéias homéricas, mas também as tragédias gregas, as Metamorfoses de Ovídio ou outros textos que trouxessem alguma informação sobre quem foram Pirra, Nestor, Níobe, Laertes, Príamo e Tiestes. Todos os seis têm em comum o traço da vetustez. Três deles são, na poesia antiga, paradigmas de homens longevos: Príamo, rei de Tróia e pai de Heitor, que, à época da guerra que destruiu sua cidade, já era de idade muito avançada; ${ }^{6}$ Nestor, rei da ilha de Pilos e aliado dos gregos na guerra de Tróia, conselheiro dos gregos por sua experiência de vida e sabedoria; ${ }^{7}$ Laertes, pai de Ulisses/Odisseu, a quem ajudou

6 Sua esposa Hécuba, igualmente idosa, era citada como paradigma feminino da longevidade (mas também da fecundidade: alguns autores lhe atribuem cinqüenta filhos).

7 Diz a lenda que Nestor era o único sobrevivente de uma grande família, massacrada por Hércules, e que o deus Apolo lhe concedera, como consolação, somar aos seus anos de vida os anos todos de seus parentes assassinados. 
na luta contra os pretendentes de Penélope (já idoso, fora rejuvenescido pela deusa Atena para auxiliar o filho nessa luta). As figuras de Príamo, Nestor e Laertes eram usadas pelos escritores antigos como exempla toda vez que pretendiam fazer referência ou caracterizar alguém muito idoso. Quanto a Níobe, fora a primeira mulher mortal e mãe da raça humana (a "Eva" dos gregos, digamos). ${ }^{8}$ Pirra era filha de Epimeteu e Pandora e esposa de Deucalião (o correspondente grego do Noé bíblico). Depois do dilúvio, como ela e o marido eram os únicos sobreviventes, tornou-se a segunda mãe da raça humana. Tiestes, por fim, era filho de Pélops e bisneto de Zeus (nesse caso, o traço de vetustez é menos evidente: seria porque Tiestes era um descendente não muito distante do Pai dos deuses?).

Marcial diz que Plútia é "filha de Pirra", a primeira mulher humana depois do dilúvio; "madrasta de Nestor", portanto, mais velha que ele, muito provavelmente; diz ainda que já tinha cabelos brancos quando Níobe, a primeira mulher mortal, era ainda uma menina; Laertes, quando já velho, chamou-a de avó, o que implica que era muito mais velha que ele; por fim, diz-se que Plútia cuidou de Príamo quando este era ainda uma criancinha, e que foi sogra de Tiestes. Enfatizase a senilidade de Plútia, pois, quanto mais velha ela for apresentada, mais estranho será que ela sinta desejo sexual, e, conseqüentemente, maior o efeito de humor do final do poema. Como afirmado há pouco, o destinatário teria de conhecer essas figuras mitológicas para captar o humor nelas presente e apreciar o humor final em toda a sua plenitude. É de se esperar que o leitor/ouvinte de Marcial tinha esses conhecimentos, até porque, como já mencionado no parágrafo anterior, alguns deles correspondem a paradigmas, ou seja, a imagens recorrentes na literatura greco-latina.

Resta comentar o verso 5, que também demanda um certo conhecimento do leitor/ouvinte, embora seja mais um conhecimento de mundo do que propriamente de outros textos. Na Antigüidade, havia a crença de que as gralhas viviam o equivalente a várias gerações humanas. ${ }^{9}$ Assim, quando Plútia morreu, teria vivido mais do que todas as gralhas. Essa imagem hiperbólica se soma, para a enfatização da senilidade de Plútia, às hipérboles intertextuais comentadas anteriormente.

8 Não confundir com a Níobe esposa de Anfião, rei de Tebas, que foi transformada em pedra por ofender Leto, mãe de Apolo e Diana.

9 Na nossa cultura, uma imagem equivalente poderia ser representada pela tartaruga, com a diferença de que não se trata de crença, mas de constatação científica. Numa tradução-recriação do epigrama de Marcial em língua portuguesa poder-se-ia utilizar a imagem desse animal. 
Aproveitemos o mesmo epigrama em questão para comentar mecanismos de produção de humor já tratadas nos outros tópicos. Poderíamos talvez pensar que o nome próprio Plutia está também produzindo humor no epigrama, na medida em que é possível ver nele a raiz de Pluto, "Plutão", o deus dos Infernos. Essa leitura é tentadora, já que Plútia é apresentada, no epigrama, como já morta. Outra possibilidade, menos provável, é associar o nome ao verbo prurire ("ter/sentir desejo sexual”), que aparece no penúltimo verso e é o principal termo desencadeador do humor.

Vê-se, por isso, que o fecho cômico é, de certa forma, antecipado, pois não se situa no último verso, mas no verbo prurit do penúltimo. A expressão cum caluo Melanthione, ao ser inserida no último verso, acaba enfraquecendo o humor final, a não ser que queiramos situar o humor principal nessa expressão, interpretandose o fecho cômico da seguinte maneira: a velha Plútia ainda consegue sentir desejo, mesmo estando enterrada com um marido calvo/feio. Creio que não é a melhor interpretação, e é por isso que, em minha tradução, faço com que "arde de desejo" (prurit) "feche" o epigrama. ${ }^{10}$

Outro ingrediente intertextual produtor de humor no epigrama sobre Plútia está relacionado à questão do gênero. O poema é construído como se fosse um epitáfio em versos, uma inscrição tumular, um poema sepulcral: o epigrama volta à sua origem mais remota. Na Antigüidade, o epitáfio, em verso ou não, era um gênero discursivo-literário, com regras e fórmulas próprias: elogio das qualidades físicas e virtudes do falecido, presença de expressões dêiticas, uma certa metalinguagem (o falecido ou o próprio túmulo se dirigem ao passante), maldições e ameaças a quem desrespeitar o sepulcro, conselhos para se aproveitar a vida (carpe diem), pedidos dirigidos aos deuses em favor do falecido, etc. Em nosso epigrama, os cinco primeiros versos se encarregam da descrição da falecida, como

10 Vale a pena comentar a sintaxe expressiva dos dois versos finais do poema, ainda que isto não esteja contribuindo na produção de humor: no meio do sintagma hoc in sepulchro ("neste sepulcro"), o poeta inseriu o particípio passado sita e o verbo prurit, ambos referindo-se a Plutia, que só vai aparecer no verso seguinte. Assim, o poeta representa materialmente, em seu texto, a idéia que esse texto traz: sita e prurit, formas verbais relacionadas a Plutia, estão no meio do sintagma hoc in sepulchro assim como Plútia está no meio, dentro do sepulcro.

O mesmo se dá no último verso, em que Plutia foi inserida no meio do sintagma caluo cum Melanthione, indicando materialmente, visualmente, no texto, que Plútia está sepultada junto de, nos braços de seu marido (?) Melântio. 
se estivesse apresentando a um passante a pessoa ali sepultada. No verso 6 há a expressão dêitica in hoc sepulchro, "neste sepulcro", principal dado que permite ver no poema uma imitação do discurso do epitáfio. E por fim a informação de que Plútia está sepultada junto de Melântio. O poema de Marcial está, portanto, "dialogando" claramente com a tradição do epitáfio em verso, ou seja, com o gênero epitáfio. O intertexto se dá então no plano genérico, mais do que com autores individualmente. E esses procedimentos intertextuais provocam humor porque Marcial opera uma quebra nas expectativas do leitor, inserindo na fôrma de um gênero sério, austero - o epitáfio ou poema sepulcral - elementos de humor, típicos do epigrama canônico: uma velha muito velha que morreu e continua tendo apetite sexual. Há claramente um rebaixamento de tom, algo que o poeta, em outros epigramas, faz também com os gêneros épico e trágico. ${ }^{11}$

Vimos que o epigrama sobre Plútia agencia uma série de mecanismos intertextuais produtores de humor, mas que se pode captar a graça do poema sem entender essas alusões, já que o efeito de humor está no fato de que a mulher idosa ainda arde de desejo sexual. Resta agora analisar um epigrama (VIII.6) em que a intertextualidade é essencial, condição sine qua non para se captar o humor:

Archetypis uetuli nihil est odiosius Eucti

(ficta Saguntino cymbia malo luto),

argenti furiosa sui cum stemmata narrat

garrulus et uerbis mucida uina facit:

"Laomedonteae fuerant haec pocula mensae:

ferret ut haec, muros struxit Apollo lyra.

Hoc cratere ferox commisit proelia Rhoetus

cum Lapithis: pugna debile cernis opus.

Hi duo longaeuo censentur Nestore fundi:

pollice de Pylio trita columba nitet.

Hic scyphus est in quo misceri iussit amicis

largius Aeacides uiuidiusque merum.

11 Pode-se dizer que esse humor está, portanto, no arquitexto, para usarmos a classificação de Genette. Para esse autor, a arquitextualidade é um dos tipos de transtextualidade e se define como "o conjunto das categorias gerais ou transcendentes - tipos de discurso, modos de enunciação, gêneros literários - que tornam cada texto singular", "as características de um texto que permitem filiá-lo a um gênero" (1982: 7ss). 
Hac propinauit Bitiae pulcherrima Dido

in patera, Phrygio cum data cena uiro est."

Miratus fueris cum prisca toreumata multum, in Priami calathis Astyanacta bibes.

Que as antigualhas do velho Eucto nada é pior

(de Sagunto as cerâmicas prefiro)

quando a estirpe maluca ele expõe de suas pratas

e, falando, essa gralha o vinho estraga:

"De laomedôntea mesa foram estes copos;

p'ra os ter, lira apolínea ergueu muralhas.

Com esta cratera Reto audaz lutou com os Lápitas:

vês na obra os estragos dessa luta?

Têm por Nestor longevo fama estes dois vasos:

por mão pília polida, a pomba brilha.

Foi nesta taça que ordenou servir o Eácida, aos amigos, mais farto e ardente vinho.

Dido belíssima a Bícias esta pátera

passou, quando um jantar foi dado ao Frígio."

Bem admiradas estas velhas pratarias, bebe-se em copos de Príamo Astíanax!

Eucto é um velho gabola, "exibido", que fica se gabando da antigüidade e nobreza de seu aparato de mesa, todo em prata (copos, taças, vasos de beber, crateras, páteras). A genealogia, as origens que ele atribui à sua prataria são tão absurdas, mentirosas (v. 3), que as palavras de Eucto até estragam o vinho (v. 4). Marcial chega a dizer serem preferíveis as taças feitas em Saguntum, ${ }^{12}$ que eram de argila (v. 2). Eucto procura conferir origens mitológicas e nobres aos seus copos e taças, num tom solene e exagerado: os copos (pocula) pertenceram a Laomedonte, rei de Tróia antes de Príamo, seu filho, e foram cobiçados mesmo pelo deus Apolo ${ }^{13}$

12 Ficava na Hispânia Tarraconense e era célebre por sua produção de cerâmica (corresponde à atual Sagunto, próxima a Valência, na Espanha).

13 Zeus havia condenado Apolo e Posêidon, que tinham conspirado contra ele, a servir o rei Laomedonte. Este encarregou as divindades de construir as muralhas de Tróia, que se tornaram, por isso, imbatíveis. $\mathrm{O}$ rei, porém, não quis pagar-lhes o preço combinado, 
(vv. 5-6); a cratera (cratera) serviu de arma ao centauro Reto na luta que ele e os outros centauros travaram contra os Lápitas na festa de casamento de Pirítoo ${ }^{14}$ (vv. 7-8); os dois vasos de beber (fundi) pertenceram a Nestor (já nosso conhecido do epigrama X.67) e as incrustações da peça, que representam uma pomba, foram tocadas pelo polegar do rei de Pilos (vv. 9-10); a taça (scyphus) foi utilizada por Aquiles, de epíteto "Eácida" porque era neto de Éaco (vv. 11-12); a pátera ${ }^{15}$ foi a que a rainha Dido, de Cartago, passou a Bícias, companheiro de Enéias ${ }^{16}$, depois de fazer uma libação aos deuses no banquete que ofereceu ao herói troiano (vv. 13-14). ${ }^{17}$

Todas essas referências mitológicas constituem intertextos sobretudo com a Ilíada, a Odisséia e a Eneida e contribuem na construção da argumentação de Eucto em favor da antigüidade e nobreza de seu aparato de mesa; contribuem, portanto, para o humor, na medida em que já se anuncia, no v. 3, que essa genealogia é maluca (furiosa) e Eucto, portanto, um mentiroso. Porém, é nos dois últimos versos (no fecho cômico) que se situa o dado intertextual responsável pelo humor principal do epigrama; a não compreensão desse intertexto impossibilita totalmente captar a graça, o humor do epigrama. O leitor previsto por esse texto de Marcial deveria saber quem foram Príamo e Astíanax, para o que bastaria conhecer a Ilíada, ou qualquer obra, grega ou latina, que tematizasse a saga troiana, ou ainda qualquer obra em que esses personagens estivessem presentes ou fossem ao menos citados. Deveria saber que Príamo, um dos paradigmas de longevidade na literatura clássica, era avô de Astíanax, o pequeno filho de Heitor e Andrômaca que morreu ainda criança, logo após a queda de Tróia. O humor do epigrama, então,

o que atraiu sobre a cidade a ira desses deuses. Eucto diz, no poema, que seus copos eram os objetos que Laomedonte havia prometido a Apolo em troca de seu auxílio na construção das muralhas.

14 Os Lápitas eram um povo da Tessália e parentes dos Centauros, embora fossem humanos. Um dos Lápitas, Pirítoo, amigo de Teseu, casou-se com Hipodâmia, e, para a festa de casamento, convidou seus parentes semi-eqüinos. Estes se excederam no vinho e tentaram violar a noiva, o que causou uma sangrenta batalha entre Lápidas e Centauros no local da festa. Eucto invoca as marcas da luta na cratera como provas de que o objeto estivera mesmo na mesa do festim de casamento de Pirítoo (cf. Odisséia, XXI, 303ss).

15 Taça de metal usada pelos romanos em sacrifícios.

16 Dito no poema vir Phrygius, "varão frígio", porque Tróia, a pátria de Enéias, ficava na Frígia, nome com que se referia genericamente, por vezes, a toda a Ásia Menor.

17 Cf. Eneida I, 740-744. Veja também I, 498-501 e IV, 60-64. 
está no fato de que os convidados de Eucto beberão, em taças supostamente antigas, velhas ("cálices de Príamo", "cálices do tempo de Príamo"), um vinho novo ("Astíanax'), e, portanto, ruim, não envelhecido. Ou seja, de que valem taças e copos nobres por sua antigüidade se o vinho é novo, de má qualidade?

Deve-se notar ainda que o humor do epigrama também está no fato de que o mundo nobre e elevado da épica é trazido, por meio das referências intertextuais, para um contexto "baixo", jocoso, o da poesia epigramática. Assim, a intertextualidade atua também no plano genérico para produzir o humor, ou seja, o humor está também no arquitexto (cf. supra, nota 11).

\section{Polissemia}

Marcial explora freqüentemente os diversos sentidos das palavras para produzir humor, como se viu no epigrama sobre Cândido. Naquele caso, porém, esse humor "polissêmico" presente em candidus era auxiliar, acessório. No dístico a seguir, o humor essencial do poema depende da polissemia do adjetivo niueus:

Sordida cum tibi sit, uerum tamen, Attale, dicit, quisquis te niueam dicit habere togam (IV.34)

Suja é a toga que tens, mas diz, Átalo, o certo quem diz que tu tens uma toga nívea.

Niuea significa "nívea", "de neve", "que diz respeito à neve", mas também "branco", "alvo", "branco como a neve" (essa polissemia também existe em português). A graça do poema está no fato de que a toga de Átalo é imunda, velha, surrada (cf. sordida, v. 1), de forma que a única propriedade que compartilha com a neve (que permite chamá-la "nívea") é que, por ser velha e surrada, é fria, gelada como a neve. A toga, assim, não é branca como a neve, mas fria como ela. Acrescente-se um curioso paradoxo: uma toga que é "nívea" não protege dos rigores da... neve.

E quanto ao nome Átalo (Attalus), seria uma escolha aleatória por parte do poeta? É difícil precisar, e o que se expõe a seguir é pura especulação: não estaria Marcial pensando em Átalo I, rei de Pérgamo, que se tornou célebre, na Antigüidade, por suas riquezas? Assim, o nome do indivíduo satirizado por Marcial contrastaria risivelmente com sua pobreza de sujeito que não tem sequer uma toga limpa e nova para vestir. 


\section{Morfologia}

Minxisti currente semel, Pauline, carina.

Meiere uis iterum? Iam Palinurus eris (III.78)

Ia o barco e mijaste uma vez, ó Paulino.

Mijando outra vez, serás Palinuro.

Para o leitor moderno, o humor desse epigrama é de difícil compreensão (e talvez também o fosse para o leitor da época de Marcial), pois são necessários um conhecimento da língua grega, uma operação epilingüística (cf. Possenti, 1998: 72) e ainda um conhecimento intertextual.

O gatilho do humor desse epigrama é o substantivo Palinurus, nome do piloto da nau do herói grego Enéias em sua viagem em direção à Itália. Marcial utiliza uma falsa etimologia para esse nome: $\pi c^{\alpha} \lambda \iota v$ (pálin, advérbio, "de novo", "outra vez") e ov $p \varepsilon i ̂ v$ (ourein, verbo, "urinar"). Assim, o poeta se dirige a um certo Paulino (o nome certamente foi escolhido por ser sonoramente parecido com "Palinuro" e permitir, assim, o jogo de palavras) que teria urinado de cima de um navio em movimento, e brinca dizendo que Paulino, se urinar de novo (pálin ourein), será um "Palinuro", será "como Palinuro". Para entender a graça do epigrama, o leitor terá de realizar a operação morfológica que fundamenta essa falsa etimologia: Paulino urinou uma vez com o navio em movimento; se urinar (ourein) de novo (pálin), será Palinuro (pálin ourein).

Mas o humor do epigrama pode ser incrementado pelo intertexto. No canto VI da Eneida (vv. 337ss.), Enéias se depara nos Infernos com a sombra de seu timoneiro Palinuro, que lhe conta ter caído ao mar por acidente e falecido nas mãos de bárbaros na terra em que o jogaram as ondas. O corpo de Palinuro está insepulto e, portanto, não pode atravessar o lago Estige e entrar na morada dos mortos. Pode-se pensar, então, que Marcial dá um conselho a Paulino, ou, mesmo, lança-lhe uma ameaça: se ele urinar outra vez com o navio em movimento, terá o mesmo destino que o timoneiro de Enéias, Palinuro (ou porque é perigoso urinar com o navio em movimento ou porque os outros marinheiros vão lançá-lo ao mar como castigo por ele urinar de cima do navio). Resumindo, então, as duas interpretações, Paulino será Palinuro por um desses dois motivos (ou por ambos): 1) porque Paulino urinou de novo (e "Palinuro" teria as raízes de pálin ourein, "urinar de novo") e 2) porque Paulino terá o mesmo destino de Palinuro, timoneiro de Enéias que caiu e morreu no mar. No primeiro caso está envolvido um mecanismo 
lingüístico morfológico (além de um conhecimento da língua grega por parte do leitor/ouvinte); no segundo, além do procedimento morfológico, um procedimento intertextual (o leitor deveria conhecer, de alguma forma, a epopéia virgiliana, ou ao menos a passagem em que se narra a desventura de Palinuro). Ambos os elementos se misturam e interagem na produção do humor desse poema. Eu diria até que a alusão, feita por Marcial, a um personagem do mundo grego serviria de pista ao leitor do epigrama para que ele dissecasse o termo Palinurus nas raízes gregas "presentes" em sua composição. O intertexto seria então uma "chave" de leitura, um alerta para o leitor de que o termo é grego e de que o humor do fecho cômico depende dos elementos gregos segmentados nesse termo.

Outros casos de produção de humor baseada em operações morfológicas foram vistos nos epigramas analisados nos tópicos anteriores: em VII.83, no nome próprio Lupercus, formado a partir de lupus; em X.67, em Plutia, que cogitei ser formada a partir de Pluto (para mais detalhes, cf. supra).

\section{Ironia}

O epigrama a seguir (II.65) é um dos muitos que têm por tema a herança. $\mathrm{O}$ poeta se dirige a um certo Saleiano, que acabou de perder a esposa:

Cur tristiorem cernimus Saleianum?

"An causa leuis est?" inquis "extuli uxorem".

O grande fati crimen! O grauem casum!

Illa, illa diues mortua est Secundilla, centena decies quae tibi dedit dotis?

Nollem accidisset hoc tibi, Saleiane.

Saleiano mais triste nós vemos, por quê?

"Achas pouco o motivo? Enterrei minha esposa!"

Ó, grande erro do fado! Ó cruel desventura!

Secundila morreu, ela, aquela ricaça

que um milhão de sestércios deixou-te por dote?

Pena que isso te foi ocorrer, Saleiano!

Creio não haver necessidade de explicar muito o humor do poema, que é evidente e de fácil apreensão. A partir do v. 3, Marcial constrói um discurso total- 
mente baseado na ironia, isto é, dizendo algo diferente daquilo que quer realmente significar. Diante da explicação de Saleiano para a sua tristeza, o poeta lança falsas exclamações lamentando a morte da mulher (v. 3), faz referência, como que desinteressadamente, à fortuna que ela deixou a Saleiano (o dote que trouxe consigo quando se casaram, vv. 4-5) e termina com a sarcástica enunciação do desejo de que aquela "desgraça", a morte da mulher, não tivesse acontecido ao indivíduo. Pode-se pensar em duas interpretações ligeiramente diferentes para o epigrama. Na primeira, Saleiano realmente lamenta a perda da mulher e o poeta tenta abrirlhe os olhos para as vantagens que ele pode tirar disso, ou seja, o dinheiro todo que ele tem para gastar. Na segunda, mais interessante, pode-se imaginar que o poeta conhece o verdadeiro caráter interesseiro de Saleiano, e insinua que suas demonstrações de tristeza são falsas, aparentes. Isso amplificaria, a meu ver, o humor do texto, uma vez que confere força ao discurso irônico dos vv. 3-6. Pode-se pensar mesmo que Marcial sugere sutilmente que foi Saleiano quem causou a morte da esposa, com a qual tinha se casado por interesse (a mulher poderia ser uma velha rica e feia, por exemplo). Na Roma da época de Marcial, parece terem sido comuns os "caçadores de heranças", indivíduos que cortejavam, cercavam de cuidados ou mesmo se uniam matrimonialmente a pessoas ricas prestes a morrer ou com poucos anos de vida. Na obra do poeta, há muitos epigramas em que esse tipo social é alvejado. Mas aí já se está no campo das hipóteses, das especulações feitas sobre elementos que não estão explicitamente no texto.

\section{Conclusões}

Muito ainda poderia ser dito sobre o humor dos epigramas de Marcial. Poderiam ser citados, por exemplo, inúmeros outros epigramas em que foram utilizados os mecanismos de produção de humor analisados no decorrer deste estudo, sobretudo aqueles baseados na polissemia e na intertextualidade, que são provavelmente os mais comuns. Técnicas como o fecho cômico, presentes na grande maioria dos poemas de Marcial, poderiam ser ainda copiosamente ilustradas, pois exemplos não faltam. A questão do gênero, aparentada à da intertextualidade, também mereceria um estudo mais detalhado, assim como o poder dos termos "obscenos" de produzir ou amplificar o humor. Os temas tratados nos epigramas, que nos são muitas vezes familiares, por freqüentarem também os textos humorísticos de hoje em dia, poderiam ser elencados e classificados. Seria interessante estudar, através do humor desses poemas, os estereótipos da sociedade romana do início do Império. A questão da tradução do humor também poderia render mais 
de um artigo, preconizando, por exemplo, que se deve deixar para o final, também na tradução, o fecho cômico do epigrama, sob pena de não reproduzir devidamente o humor do original.

Todas essas questões, porém, devem ser tratadas ou melhor desenvolvidas em estudos à parte. O espaço de que aqui se dispõe não pode abarcar tantas investigações e devo me contentar em resumir as conclusões obtidas a partir do que pôde ser efetivamente exposto neste trabalho. Assim, verificou-se que os mecanismos produtores de humor em latim e em português não diferem muito; o que muda é o material envolvido. Em latim, portanto, tem-se humor decorrente da ambigüidade lexical, da ironia, de procedimentos epilingüísticos (morfológicos, fonológicos) e de intertextos, assim como ocorre nas piadas e outros textos humorísticos em língua portuguesa (e em outras línguas). Uma análise mais detalhada dos 1555 epigramas de Marcial poderia detectar ainda outros mecanismos produtores ou amplificadores do humor, o que certamente aumentaria a lista das semelhanças com os mecanismos presentes nos textos atuais dessa natureza.

Verificou-se também que, em geral, mais de um mecanismo é agenciado num mesmo epigrama para a produção do humor, ainda que esses mecanismos obedeçam a uma hierarquia de importância no processo, havendo aquele(s) responsável(is) pelo humor essencial e aquele(s) responsável(is) pelo humor acessório.

\section{REFERÊNCIAS BibliográficAS}

CESILA, Robson Tadeu. Metapoesia nos epigramas de Marcial: tradução e análise. Campinas: IEL/UNICAMP, 2004 (Dissertação de Mestrado em Lingüística/ Letras Clássicas).

CITRONI, Mario, FEDELI, Paolo, PADUANO, Guido, PERUTELLI, Alessandro.

La poesia latina: forme, autori, problemi. A cura di Franco Montanari. Roma: La Nuova Italia Scientifica, 1991.

CONTE, Gian Biagio. Latin literature: a history. Trad. inglesa de Joseph B. Solodow. Baltimore-London: Johns Hopkins University, 1994.

GENETTE, Gérard. Palimpsestes. La littérature au second degré. Paris: Seuil, 1982.

GENTILI, B., STUPAZZINI, L., SIMONETTI, M. Storia della letteratura latina. Roma-Bari: Laterza, 1987.

MAINGUENEAU, Dominique. Elementos de Lingüística para o texto literario. Trad. Maria Augusta B. de Mattos. São Paulo: Martins Fontes, 1996 (a). 
. Pragmática para o discurso literário. Trad. Marina Appenzeller. São Paulo, Martins Fontes, 1996 (b).

. O contexto da obra literária: enunciação, escritor, sociedade. 2.ed. Trad. Marina Appenzeller. São Paulo, Martins Fontes, 2001.

MARCIAL. Epigramas. Trad. de Delfim Ferreira Leão (Livro dos Espetáculos), José Luís Brandão (Livros I e II) e Paulo Sérgio Ferreira (Livro III). Lisboa: Edições 70, 2000. v.1. (Clássicos Gregos e Latinos).

MARTIAL. Épigrammes. 2.ed. Texte établi et traduit par H. J. Izaac. Paris: Les Belles Lettres, 1961. 3v.

. Épigrammes. Texte établi, traduit et annoté par Pierre Richard. Paris: Garnier Frères, 1931. 2v.

MARTIN, R \& GAILLARD, J. Les genres littéraires à Rome. Paris: Nathan, 1981.

POSSENTI, Sírio. Os humores da língua: análises lingüísticas de piadas. Campinas: Mercado de Letras, 1998.

PROPP, Vladimir. Comicidade e Riso. São Paulo: Ática, 1992.

SWANN, Bruce W. Martial's Catullus: the reception of an epigrammatic rival. Hildesheim/Zürich/New York: Olms, 1994.

CESILA, Robson TAdeu. Mechanism of Humor in Martial's

ABSTRACT: This paper aims to describe some devices that act for producing humor in the epigrams of Martial.

KEYWORDS: epigram; Martial; humor; lanch. 